\title{
Eating in the Nursery School: Pedagogy, Performativity \& Biopolitics ${ }^{1}$
}

\author{
Michalis Kontopodis*
}

\begin{abstract}
The study presented here explores eating as a pedagogical practice. It pays attention to arrangements of things such as Christmas cookies, whole-wheat and white bread, frozen chicken, plates, chairs, tables, and freezers. Entering in dialogue with performativity theory and post-structuralist approaches, a series of ethnographic analyses from German and Brazilian nursery schools reveal how eating can be enacted as a sensual pleasure, a health risk, an ethnic custom, or a civil right within a variety of local pedagogical contexts. Through specific arrangements of foods and other things, young children are educated to eat with moderation, to change their ethnic dietary habits, or to become modern citizens. Pedagogy can thus entail doing public health, doing ethnic identity, or doing citizenship while eating is an important way of doing these in early childhood education and care settings.

Keywords: Early Childhood Education \& Care; Ethnicity; Obesity Prevention, Performance.
\end{abstract}

\section{Comendo na escola infantil: Pedagogia, Performatividade \& Biopolítica}

\section{Resumo}

O estudo apresentado aqui explora o ato de comer como uma prática pedagógica. Tem-se como proposta prestar atenção aos arranjos de comidas como biscoitos de Natal, pão de trigo integral e pão branco, frango congelado, pratos, cadeiras, mesas e congeladores. Através do diálogo com a teoria da performatividade e abordagens pósestruturalistas, uma série de análises etnográficas de escolas de educação infantil alemãs e brasileiras revelam como comer no jardim de infância pode ser um prazer sensual, um risco para a saúde, um costume étnico, ou um direito civil dentro de diferentes histórias locais e constelações de poder. Através da combinação de alimentos específicos e outras coisas, as crianças são educadas para comer com moderação, para mudar seus hábitos alimentares étnicos, ou para serem cidadãos modernos. A pedagogia pode, portanto, consistir em fazer valer a saúde pública, fazer valer a identidade étnica, ou fazer valer a cidadania e comer é uma forma importante de fazer isso em configurações de educação e nos cuidados na primeira infância.

Palavras-chave: Educação da primeira infância e Cuidado; Etnicidade; Prevenção de obesidade; Performance.

\section{Eating as a Pedagogical Practice}

The pedagogical dimensions of eating have been widely discussed since the very beginning of Western philosophy - especially when referring to feeding and taking care of the newborn (ALTHANS; BILSTEIN, 2016). When referring to preschool and school-aged children, eating has been studied as a ritualized performance that is culturally and historically shaped and entails the dynamic negotiation of power relations - most importantly of the pedagogical authority of adults over the children (AUDEHM, 2007). Many sociologists of childhood have also studied the various ways in which Western civilizations and schools in particular "educate" the child body, which entails the transmission of values about eating (SHILLING, 2008).

But how exactly is eating done in the nursery school and what are the pedagogical values enacted during eating? Which are the roles of things such as plates, furniture, or foods in doing pedagogy? How do eating settings in nursery schools reflect local eating habits, local histories of schooling and local histories of public health policies? Which are the tensions and power constellations that are entailed and negotiated in eating settings in nursery schools?

In the following pages I will explore these questions on the basis of ethnographic research materials from nursery schools that have developed specific concerns about food and eating. I will pay attention to things as well as to the corporeal and performative aspects of action (KONTOPODIS, 2012a; MOL 2008a; WULF and ZIRFAS, 2007). I will not present though more details on theory and methodology here, and I will also not follow the typical structure of an academic article below: instead I will let my argument unfold in three steps through the parallel presentation of methodological details, ethnographical data and theoretical discussion. ${ }^{2}$

For purposes of contrast and given the space limitations of a journal article, I will refer to concrete examples from research materials from three nursery schools: two nursery schools that were located in Berlin, Germany, and another one located in the countryside of Espírito Santo, Brazil. ${ }^{3}$ The German

\footnotetext{
*Endereço eletrônico: m.kontopodis@ @ sheffield.ac.uk
} 
kindergartens participated in a large-scale obesity prevention program created by the General Funds for the Local Ill${ }^{4}$, which significantly modified the eating practices in the nursery school. The Brazilian nursery school participated in the National Program of School Alimentation (Programa Nacional de Alimentação Escolar) while at the same time developed a specific pedagogy that was oriented towards small-scale agro-ecological production (Pedagogia da Terra). These programs generated a variety of tensions in pedagogical practice that reflected contradictory local histories and power constellations.

\section{Whole-wheat or White bread? Identity Politics in Berlin}

"I am as usually video-recording while standing next to one of the classroom walls with a small camera. The meal for today is fish fingers with potatoes and a sauce made with oil, flour, and vinaigrette. What makes the setting unusual is that I have placed a platter on each table containing equal amounts of whole-wheat and white bread. Samira (pseudonym) who is about 3 years old is joyful about my presence; she is one of the children that I have followed ethnographically for a few weeks. She has already had a first portion and then goes back to the tray with all the food, taking two more fish fingers, potatoes, and as much sauce as her plate can hold.

After eating the potatoes and the fish, she takes quite a big piece of white bread and first with her right, then also with her left hand she puts the bread onto the plate and tries to soak up as much sauce as possible and then eat the bread with all this sauce. Often, while she repeats this, she licks one or more fingers and smiles to the camera and the children sitting around her. This happens six or seven times, then she takes more sauce and more bread and repeats the same until there is no sauce left. The plate looks like it has been cleaned; she lifts it up and shows it around while licking her lips. The other children around, who have eaten in a similar way, look at her and smile. When everybody is finished, most of the white bread is eaten, while the whole-wheat bread is left almost intact. Similar interactions among the children during eating have taken place in other occasions, also when I was not filming" (ethnographic fieldnotes and transcription of video-recording by the author).

The scene above was part of a quasiexperiment (DINARDO, 2008) in a kindergarten located in Wedding, part of former West Berlin and more concretely in a neighborhood where many migrant families, mostly of Turkish or Arabic ethnicity, live. I designed the quasi-experiment as part of my research there. The experiment consisted of providing the young children with both white and whole-wheat bread for their lunch and exploring what would happen. It became clear that children could use the different breads for different functions: The white bread was soft and could absorb sauce. The whole-wheat bread was sturdy, so one could put things like cucumber or tomato on a slice of that bread.

Culture became here materialized in an interesting way, because the young children of Turkish and Arabic ethnicity were used to having bread with food, using their fingers and enjoying the sauce or the olive oil of the salad in the way Samira did above. Children and teachers of German ethnicity were instead used to eating harder whole-wheat bread cut into slices, with cheese or ham and some green stuff on it. This type of bread was mostly used for snacks and if it accompanied a soup, it would not be soaked in it but eaten separately - not to mention that children of German ethnicity would most probably be obliged to try to use a fork and a knife for eating and would not easily be allowed to put bread in the soup/sauce while touching the food with their fingers.

Children aged 3-4 years old like Samira had already developed know-how for such things. It was remarkable for the German teachers that the sauce was made just to be put on the potatoes (in what would have been a typical German dish for children) but Samira enjoyed the sauce and the bread in a different way than the teachers had expected. Taking into consideration her whole performance of licking fingers and filling the plate with sauce again and again, eating seemed to be a sensual pleasure that Samira enjoyed - a feeling she communicated to the other children around her.

This logic that eating is a sensual pleasure contradicted, however, to the teachers' logic based on the guidelines by the General Funds for the Local Ill (AOK): Since the beginning of the kindergarten period, all the teachers (who were German) had complained that parents of Turkish or Arabic ethnicity were giving their children white bread with cheese or ham (instead of whole-wheat bread) to eat as snacks in the nursery school as well as to eat at home. For the German teachers, eating was a means of providing the child body with enough nutrients (in this case fibers). The guidelines behind this logic 
were quite dogmatic and did not allow for ethnic or alternative dietary models. ${ }^{5}$ Doing public health could have happened by incorporating ethnic food preferences in German nutritional models, but this was not the case maybe because the whole-wheat bread has been significantly privileged over white bread during what has been a long history of public health policy in Germany - more than anywhere in the world (RABINOW, 1996, p. 104; SPIEKERMANN, 2001). The pedagogy resulting from those guidelines was absolute: the state, through the public kindergarten, was responsible for educating both parents and young children about what and how young children should eat i.e. eating was a matter of pedagogical authority.

There were also further differences between the teachers and parents regarding pedagogical styles and values about childhood and child-rearing, the distribution of work and authority between men, women, and the extended family, preferences about clothes, toys and (class-)room decoration/ architecture as well as preferences about food, religious habits, and celebrations. In most cases parents also did not feel comfortable in the nursery school; although they did not speak fluent German, the unofficial policy in the nursery school was that speaking German was important and that not only young children, but also parents should accept this principle inside the nursery school and in their lives in general.

The most conflictual issue between Turkish/Arabic-German parents and German teachers was however the bread that was given to young children. In this context teachers tried all possible means to educate parents to buy and prepare whole-wheat bread for their children:

- they provided whole-wheat bread with cucumber, tomato, and cheese during the parent evening, and were often disappointed that most food was left on the table;

- they rewarded children when parents gave them whole-wheat products and told the children off in the opposite case;

- they put whole-wheat bread pictures on the information board;

- they repeatedly told the children and parents that white bread is unhealthy.

Around December I showed Samira the video with her eating white bread from the abovepresented quasi-experiment. We stood in front of my computer that was connected to a beamer and before I asked any questions she pointed to the white bread on the screen and said:

Samira: I like this one! (pointing to white bread on the screen)

Michalis (researcher): You like the white?

$\mathrm{S}$ : Yes (turning her face and looking to me)

M: And can you say why?

S: My favorite bread; this is from Turkey, I

always buy it at the Turkish store and I like its

taste.

M: Could you tell me what you take with you

from home to eat here?

S: I always take cream cheese, and whole-wheat bread or cheese, with cucumbers, tomatoes, or carrots (continuing looking to me).

M: Why whole-wheat bread?

S: Because white bread is not allowed here (turning her face down).

M: Why is it not allowed?

S: I do not know (looking down to the floor and moving a little bit away).

(Transcription of video-recording by the author, translated from German by the author).

As one can tell from Samira's words, given that the tension between the German teachers and the parents of Turkish or Arabic ethnicity was high anyway, eating became a way for young children, parents and teachers to do identity politics. ${ }^{6}$ Bread enacted a relation of cultural difference as a relation of pedagogical authority and resistance on issues related to child health and nutrition. Even if the teachers principally treated all young children as being "a population at risk of obesity," children of Turkish or Arabic ethnicity were considered to be more than "at risk" than the others. ${ }^{7}$ The young children, in response, identified with the white bread by saying that it was "their" bread, they bought it from the Turkish shops in their neighborhoods, as Samira did above. The white bread became the object that symbolized Otherness for the teachers and mediated the relation between the teachers (all Germans) and the parents and young children of Turkish or Arabic ethnicity.

Interestingly enough, although the guidelines for healthy nutrition were the same as for the nursery school of the first example, bread and not the individual portion was the object through which the tension between eating for pleasure and eating for health was materialized in this second nursery school. The teachers did not collaborate in designing eating settings with the parents and the young children, but imposed their values to them. They were acting as the ones who knew what was better for the young children and what was not. Young 
children as well as parents were obliged to agree in practice, did not however accept the teachers' principles. The whole-wheat bread became a powerful and power-laden means to do ethic identity politics, and young children of Turkish and Arabic ethnicity were considered as at risk because of their ethnic backgrounds.

\section{Just One Christmas Cookie: Restricting Sensual Pleasure in Berlin Lichtenberg}

"Shortly before Christmas we were preparing traditional German Christmas cookies in a public kindergarten in the formerly East Berlin neighborhood of Lichtenberg. "We" in this case meant two teachers, about twenty children aged 3 and 4 , and myself. I had already been doing fieldwork for two months, participating in all possible activities, and everybody was familiar with my presence. The children were happy to play with the dough and make their own cookies. They wore aprons so as not to become dirty, and chef hats to make the whole event even more fun. Every child wanted to participate; we had a lot of time and a lot of dough, so we prepared dozens of cookies. Then, at noon, the children had lunch and then a nap while the cookies were transferred to the central kitchen of the nursery school to be baked.

When the children woke up, a few of them were picked up by their parents. For the rest it was time for a snack. They came into the lunchroom, where the three round tables that could each seat six children were decorated with a Christmas centerpiece that consisted of a candle placed on a wooden base, with a wreath of plastic pine tree leaves, stars, cinnamon pieces and Christmas balls. The teachers ${ }^{8}$ knew that eight children would be having a snack, and while the children were sleeping the teachers had prepared the snack by putting just one cookie on each child's plate in front of each child's chair (thus using just two of the tables i.e. four + four chairs). The rest of the cookies were kept out of the children's view. The children were supposed to sit and eat within 1015 minutes as well as to accept strict rules of movement enforced by the teacher. The teacher was visible because she stood while the children were sitting, and the room was small so that she could see everything and have eye contact with almost everybody. The rule, "when we eat, we do not speak" was also enforced as usual by the teacher's presence.

There was literally no possibility for a child to eat a second cookie, since only one cookie per child was available and all other cookies were invisible. A child could also not eat another child's cookies, since every child had a small plate in front of him/her and was definitely curious or hungry enough to start by eating this one cookie. Thus not much was happening: children ate their cookie and drank a fruit-based tea while listening to Christmas songs from the CD player. When all the children were finished, each child brought his/her plate and cup back to a tray and they moved to the next room for the next activity" (ethnographic fieldnotes and transcription of video-recording by the author).

Making young children happy was one of the requirements teachers were trained to fulfill in Germany. It was expected of them by parents and nursery school directors. This corresponded with German pedagogical traditions and is even implied in the German word kindergarten which literally means garden in which the children grow as if they were flowers (FICHTNER, 2009). Cutting an apple in a funny way, shaping cooked potatoes into stars, decorating the tables according to the time of year, baking cakes together, and especially celebrating Halloween, Christmas, and birthdays seemed to be an important part of what it was to be in the kindergarten - both as a teacher and as a child. The teachers I observed were motivated in preparing each of those celebrations.

All this had an aesthetic dimension that involved the senses: foods of particular smells and tastes in the shape of stars, trees, or hearts and, if possible, in vivid colors went together with music, candlelight, and playroom decoration. Eating was a sensual pleasure as well as a ritual activity that was important for the social life of young children and teachers as a community. ${ }^{9}$ In this context a thing like a cookie was interlinked to the child body: the shared implicit understanding was that the child's body had a particular preference for the Christmas cookie because it was sweet, smelled nice, was crispy and easy to eat, and had a nice shape.

\section{Picture 1: One Christmas cookie per child}




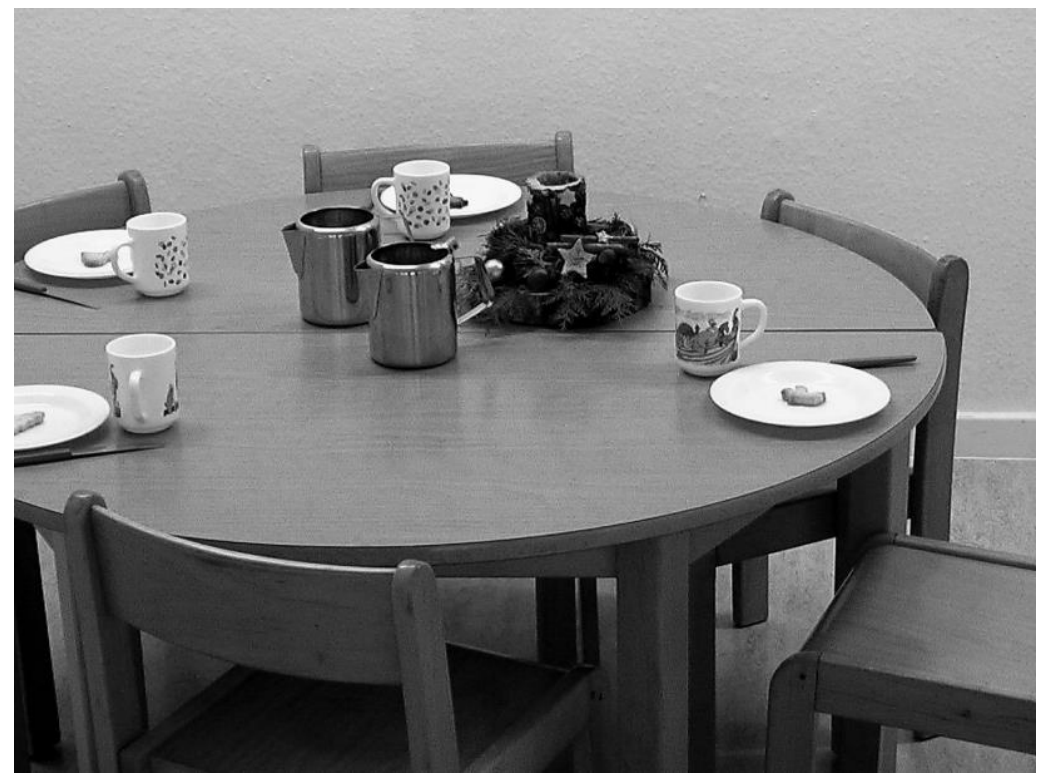

Picture taken by the author

Pedagogy was directed towards sensual pleasure but was also directed towards discipline: Coming from a different socio-cultural background, that of middle-class rural Greece, I was quite astonished that the children in this setting did not share a buffet or a big platter with many cookies, thus eating as much as they liked while socializing i.e. celebrating the coming Christmas with the others. The teachers created an arrangement of individual portions in which the things themselves, i.e. the one cookie per one dish per one chair per child at the table in combination with the given time-frame of the 1015 minutes available for this snack, controlled the young children's actions.

Every child ate the cookie in silence and no child expressed any complaint or asked for more cookies, since it looked like no more cookies would be available. The history of the arrangement of the individual portion, i.e. of a certain amount of food per child can be traced back to Protestant religious habits and former East German routines. The main reason, however, why there was no buffet or centrally available platter with a lot of cookies for each child to eat ad libitum was because, according to recent "anti-obesity" guidelines, young children must eat within limits, i.e. young children should not eat more than a particular quantity of sweets. ${ }^{10}$

Public health officials, economists, and health politicians as well as actors of the educational sector have recently proclaimed "obesity" a major epidemic in Germany on the basis of a quite long German history in the public prevention of chronic diseases. ${ }^{11}$ Although there is little agreement in regard to the causes of "obesity," a common topos among many scientists, politicians, and people working in prevention promotion is that the "obesity epidemic" can be treated most effectively by prevention practices - the earlier such practices begin, the better (KONTOPODIS, 2011). In this context, the child body's preference for the cookie was believed to be so strong that if endless cookies had been available, at least some of the children would have eaten much more than appropriate in terms of calories intake, as the teachers explained to me. Given there are often celebrations, eating more than appropriate could then lead to "obesity."

As already mentioned, the nursery school where the above-presented scene took place ran an obesity prevention program created by the General Funds for the Local Ill. The teachers had recently been further trained in applying the so-called setting approach in obesity prevention, which also included modifications of playground architecture, increased emphasis on sports, the continuous provision of fruit and water at the nursery school, and the circulation of information material about healthy nutrition.

One the one hand, teachers were thus expected to make young children happy by making, eating, and enjoying cookies as an important part of the Christmas ritual. On the other hand, they were expected to prevent young children from eating too much. The teachers found themselves obliged to combine pleasing the young children, performing community, teaching moderation, and getting children used to restricted eating. Eating was enacted both as a pleasure to which the child's body was 
"naturally drawn" and as risky for the child's body.

This tension was expressed in the pedagogy of restricted pleasure performed in the abovedescribed setting. My fieldnotes include plenty of examples of such practices: counting food quantities and regulating food intake was generally regarded by the teachers as the most significant preventive intervention at this nursery school. Teachers did not discuss with the young children how to deal with the different logics of eating. ${ }^{12}$ They also did not create with the children a setting for eating cookies. Instead, the teachers prepared the eating setting for the children without the children, while children were sleeping.

The teachers performed therefore pedagogical authority, which went together with the non-participation of the young children in creating their everyday-life settings and activities in the nursery school. The ordering of one cookie per plate per chair per child within a short time-frame mediated this relation between the teachers and the young children while valuing health over sharing and eating food without restrictions was the mode of expression of pedagogical authority. Young children were expected not just to learn to eat with moderation, but also to accept the teachers' authority. In this sense eating was a way to do pedagogy by other means i.e. not through plays, child books and songs or learning activities but be means of individual portions and restricted access to cookies. Doing pedagogy in this way was more implicit but also more powerful than e.g. teaching moderation by means of story telling or theatre playing would be. Pedagogy merged in this way with biomedical science and teachers became "health experts" (EVANS; DAVIES, 2004, p. 39).

\section{Frozen Chickens \& Social Justice in the Countryside of Espírito Santo}

In both examples above, young children were enacted as a population at risk. Just because of their age or their ethnicity, the young children's bodies interrelated to things such as cookies or white bread, were enacted as inclined to sensual pleasure, which in principle went together with eating "unhealthy." Restricting young children so that they would not eat white bread or so that they eat just a small quantity of sweets, as well as educating them and their parents to do so in other settings, were seen as the responsibilities of teachers and public kindergartens as state institutions in the present day.

Eating sweets or enjoying a certain type of bread are not, however, "natural" inclinations of young children's bodies. Neither is early childhood education and care per definitionem concerned with health when it comes to eating. To shed more light on ways to do different pedagogies of eating, the next example will take us into a different pedagogical setting, that of a countryside nursery school in Espírito Santo, Brazil:

"Chicken boiled with tomato sauce and rice is the lunch for today at the preschool of a small village in Espírito Santo. As is the case all over Brazil, the (pre-)school serves lunch at 9.00 in the morning, i.e. between the first two and the last two hours of classes (merenda escolar). This lunch usually consists of cooked food and is prepared by the school cook. João is about 4 years old. Since I arrived he has been eager to interact with me - as are his parents - and is one of the children that I have followed ethnographically over a few days. João eats quite a big plate, as most children do. He then stands up, goes to the kitchen, and receives an extra piece of meat with some more rice and sauce, which he also eats while he makes jokes and plays with the other children sitting near him at the table. After all children have finished eating, the next school activities take place until 11.00. I then go with João to his home. It is around 12.00 when his mother prepared the table for today's meal: chicken with rice, beans, and a little bit of salad. This time the chicken is fried, and there is no tomato sauce. João eats the whole plate quickly and moves to the yard to play with the cat" (extract from ethnographic fieldnotes and transcription of video-recording by the author).

For many of Brazil's children, their school meal is in fact their only proper meal of the day. ${ }^{13}$ However, this is clearly not the case in the small village referred to above. This village has existed since 18 years, when the so-called Landless Rural Workers occupied land that belonged to a large-scale landlord. At the same time they fought for having a local small preschool and primary school within the newly established village run by teachers from the village. They were opposed to large-scale agribusiness and favored the so-called small-scale agroecology which went together with a specific pedagogics, the so-called Pedagogia da Terra (pedagogics of the land). ${ }^{14}$ Indeed, irrigation systems were built and the trees and plants have grown enough so that the agricultural production has now been sufficient for the village population's dietary needs.

Chicken with rice and beans is the most 
commonly served and eaten food in this small village. Beef with rice and beans would be the traditional Brazilian dish, but cows are expensive and require space, which the inhabitants of this village prefer to use for cultivating fruits, rice, beans, and vegetables. Chickens instead do not need much space and eat all possible organic rubbish. Every family owns chickens, as does João's. By contrast, the chicken that children eat at school is produced in large quantities by a regional industry, frozen, and then bought and transported from quite far away through the prefecture. Three years ago, when the state refused to provide the newly built school with a freezer for the frozen chicken (because the school was too small for such a huge expense), the smallscale land workers did not volunteer to provide the school with, let's say, two locally produced and fresh chickens per week; instead they volunteered to collect the necessary money and buy the freezer. The prefecture thus could deliver a certain amount of frozen chickens once per month to the school, and the cook could cook it twice or so per week.

If eating would be considered a sensual pleasure, like in the previous examples from German kindergartens, then eating the fresh and locally produced chicken at school would have been preferred over the frozen one - which was in other research fields considered to be much less tasty, at least for certain ways of cooking. Young children, parents, and teachers did not seem to distinguish at all between the fresh chicken and the frozen one, or to have any preference for the one or the other. There were no comments, facial expressions, gestures, or any sign of such a distinction.

Moreover, if eating were associated with health, as it was in the German kindergartens, one would have probably preferred the locally produced, organic chicken over the industrially produced one which contained preservatives and added hormones that could be considered toxic and hazardous for the long-term wellbeing of the young children's population. This is not to mention that there were plenty of chickens available in the village, where collective forms of agriculture were practiced and thus it would have been cheaper and easier to provide the local school with fresh chickens (ready to be cooked) than to fundraise and buy an expensive device like a freezer.

But eating in this context had very little to do with sensual pleasure or health in the sense those words had in the German kindergarten: eating at school was first of all a civil right for which social movements had fought for ages, and even if food was not indeed necessary in material terms, it was important on the symbolical level that the young children of the village were treated at school as full citizens of the Brazilian state, and enjoyed everything that all other young children had, i.e. a freezer and frozen chicken. In this setting a pedagogy of social justice was performed. In a similar way in which the arrangement of one cookie per child or the debate about eating whole-wheat bread materialized a long history of public health in Germany, the freezer materialized a long history of countryside movements for just distribution of the Brazilian wealth, for transformation of the Brazilian educational system into a system that would ensure a good quality of life according to modern standards for all.

The public nursery school was expected to take responsibility for the young children's wellbeing - yet in quite a different way than was the case with the German state in the previous examples. The local community did what the state had not yet done (i.e. buy the freezer), within a logic of local empowerment. The pedagogical message that eating frozen chicken at school entailed was: countryside young children constitute the next generation of countryside people who will continue fighting for a better future for all.

Young children were however not given much choice, but also they did not manifest any strong preference for the one or the other chicken, like young children often did for eating cookies or white bread in the German kindergartens. Furthermore no reflection took place on what the consequences of the use of expensive technology (financial, environmental, political, other) were, and the possible alternatives to this technology (e.g. traditional techniques).

\section{Doing Pedagogy by Other Means}

Even if the presented ethnographic materials have just an exemplary function, it has been manifested how eating is a way of doing pedagogy by other means in the nursery school. Following the so-called "performative turn" in educational science (WULF ; ZIRFAS, 2007), I paid attention to the dynamic interactivity between people and things. Orderings of things such as Christmas cookies, plates, whole-wheat bread, or frozen chicken enable a few things to happen while rendering other possibilities of action impossible. For example, it is easier to make individual portions by using a few plates than by using one platter. A child cannot 
simply eat sauce with whole-wheat bread; white bread is better for that. For chickens to be maintained in long-term a freezer is necessary.

Such arrangements do not operate in the same way everywhere just because of their material affordances: in Germany, a Christmas cookie is a Christmas cookie and not just a cookie, but it would not be the same cookie in the Brazilian village. This is because things do not act alone: things are what they are through their relations to other things: a cookie is a Christmas cookie not just because of its shape and the way it looks like or it tastes but in relation to room decoration, Christmas narratives, music, and young children's bodies that are developing a liking for those cookies in Germany.

In a similar way, white bread is "our" bread

for Turkish-German young children, but the opposition between white and whole-wheat bread would not make sense for the German young children. The arrangement of the individual portion is preferred over sharing food in the German kindergarten so as to control and reduce young children's food intake. The same arrangement is preferred in the Brazilian preschool for a different purpose, i.e. in order to ensure that every child eats enough; taking a second or a third portion in the Brazilian nursery school is then encouraged and rewarded while in the German kindergarten it is almost a no-go. Being able to provide countryside young children with frozen chicken in the Brazilian nursery school is a reason for the teachers and the local community to feel proud, while for middle and upper class parents in Germany this would be a shame. Eating in all these cases can be different things: a sensual pleasure, a health risk, an ethnic habit, or a civil right.

Even when moving from one nursery school to another within Berlin one can find significant differences concerning the pedagogical dimensions of eating: while teachers paid so much attention to the quantity of food consumed by young children in the Lichtenberg kindergarten which participated in the AOK-program, in the Wedding kindergarten which participated in the AOK-program they did not. One would find significant differences also when moving from one village in the region of Espírito Santo in Brazil to the next one. ${ }^{15}$

The complexity increases when new elements come into play and different logics merge with each other: a Christmas cookie on a plate on a table in front of a chair in the lunch room of the nursery school is an individual portion for that day's afternoon snack. The Protestant pedagogy of always eating with moderation (as opposed to fasting and feasting), institutionalized rules for eating in East German kindergartens (where the young children were not expected to serve themselves and were not allowed to leave food on their plates) and the long history of public health policy and prevention of cardiovascular disease in Germany (which has been re-invented in recent life-scientific discourses) and the logic of making children happy at Christmas merge with each other; as a result the ordering of Christmas cookies + room decoration + music is transformed through novel arrangements such as one plate/one cookie per person in what can be seen as an up-to-date as well as a locally-historically meaningful setting for eating Christmas cookies in the nursery school.

Pedagogy therefore does not necessarily consist in transmitting to young children a closed system of values but entails tensions and contradictions. How powerful and power-laden the pedagogy of eating can be was clear in the second example, in which the nursery school teachers did not allow Turkish-German young children to eat white bread in the nursery school. This setting materialized a long and ongoing history of privileging wholewheat bread over white bread in Germany, which began in the Third Reich but was later incorporated in other models of public health, such as the setting approach to obesity prevention in nursery schools, to which I referred above. The new element in this case was the Turkish-German young children and parents' ethnic food preferences and the symbolisms that eating whole-wheat bread entailed as opposed to white bread. Within a broader tensed atmosphere between the German teachers and the TurkishGerman parents in the nursery school, the emphasis on whether young children eat whole-wheat or white bread was not discussed in terms of public health but in terms of identity pedagogics.

In the Brazilian case, the arrangement of chicken + freezer + kindergarten materialized the history of social struggles to achieve modernstandard living conditions for Brazil's countryside population. Eating a proper meal that was provided by the state at school was considered to be a civil right, and was a way of doing citizenship, i.e. ensuring modern-life standards for the countryside young children. The nursery school was not in this case regarded as a state institution built for controlling or changing the behavior of young children and their parents; it was a state institution supported by the local community and aimed to enable countryside young children access to 
"modern" life. The frozen chicken materialized in this context the engagement of the local community to ensure the best possible conditions for the growing generation. Eating a proper meal as in any other Brazilian school was a powerful way to educate young children that they are entitled to enjoy modern life standards. This way of doing citizenship education was combined with classroom lessons on Brazilian history or civil rights and other activities such as theatre plays, as I analyze elsewhere (KONTOPODIS, 2012b). Eating tasty, fresh, or organic chicken was therefore not preferred in this setting over eating frozen ones.

Eating Christmas cookies, whole-wheat or white bread or frozen chicken in the kindergarten entails pedagogical values that often are implicit and taken for granted by the teachers, the young children, and the parents. Eating often reflects tensions and power constellations, which sometimes become explicit - like in the example of doing identity politics by means of whole-wheat bread. Other times these tensions remain implicit - like the tension between valuing modern technologies and valuing fresh chickens at the Brazilian nursery school. Paying attention to how exactly things are ordered opens new paths towards revealing, discussing openly, and questioning the tensions as well as the values that are entailed in everyday early childhood educational and care practices. Revealing, openly discussing and questioning tensions and values opens in turn possibilities to do pedagogy differently, without however adopting too quickly the one or the other position.

\section{Acknowledgements}

Discussions with A. Mol, E. Yates-Doerr, A. Mann, S. Abrahamsson, F. Bertoni, R. Ibanez, and J. Niewöhner have had a major influence on the writing of this paper and I would like to express my gratitude to them. The German Ministry for Education and Research as well as the European Research Council financed the two research projects, to which this paper refers (BMBF 01GWS5051-054 and ERC AdG09 Nr. 249397). For my research stay at the Federal University of Espírito Santo and my access to the Brazilian nursery schools I would like to thank E. Foerste and G. M. Schütz-Foerste. A special thanks is also due to the anonymous teachers, parents, and young children who participated in my research.
1 A previous version of this article was published as following: Kontopodis, Michalis (2013). Eating Christmas Cookies, Whole-wheat Bread and Frozen Chicken in the Kindergarten: Doing Pedagogy by Other Means. Zeitschrift für Erziehungswissenschaft, 16(2), 123-138.

2 My research followed the ethical guidelines and written and unwritten laws for research with young children in Germany and in Brazil: the optional and informed participation of the children; explicit agreement of the adult caretakers, of the teachers as well as of the school authorities; the maintenance of anonymity; information sensitivity; and attendance to the concerns of the research participants.

3 The name of the village is not revealed as to ensure anonymity. Child day-care in Germany starts from the age of six months. Kindergarten usually runs from three to six years and links to primary school. There exists a strong East/West difference in daycare infrastructure, with the former East offering a much better network of public day care and preschool educational settings. In Brazil the age structure is the same and the word equivalent to kindergarten is pré-escola. The quality of the public educação infantil varies a lot when moving from the South to the North and from the countryside to urban spaces. Comparing to countries such as UK or US it seems however that both the German and Brazilian states have been expected to invest a lot in public early childhood education by the local societies and significant efforts have been undertaken so that most children can attend the public kindergarten/ nursery school. In Brazil educated and richer families still prefer to register their children with private kindergartens/ nursery schools, which usually offer a higher quality early childhood education than public kindergartens.

4 In German AOK i.e. Allgemeine Ortskrankenkasse, one of the main health insurance providers within the national health care system in Germany.

5 The AOK follows relatively mainstream Western nutritional knowledge embodied in the nutritional pyramid (1. Liquids, 2. Bread, Cereal, Rice, and Pasta, 3. Fruits and Vegetables, 4. Animal Products: Milk, Dairy Products, Meat, Fish, Eggs, 5. Fats and Oils, 6. Sweets and Snacks). Children are supposed to eat a lot of the categories 1,2 , and 3 , eat with moderation from category 4 , and very little from the categories 5 and 6 and the bread (and if possible all category 2 products) should be whole-wheat. Drinks should be without calories,

\section{Notes}


i.e. water, fruit tea, or water with a little bit of juice. These guidelines are explained to children by various playful means and also followed by the kindergarten kitchens. All nutritional models are relative, however, and a recent British study that could easily apply to this German kindergarten as well (where no such study has yet taken place) would privilege the consumption of white bread because it found fibre levels in the majority of nurseries to be too high. Many were closer to the recommendation for adults. Fibre is sourced from fruit, vegetables, pulses, and wholemeal foods such as brown rice, pasta, and wholemeal bread. Too much fibre is detrimental for young children because it is bulky and filling, and so may cause insufficient food intake. Fibre also inhibits the absorption of minerals such as iron and zinc (Local Authorities Coordinators of Regulatory Services/ LACORS 2010, p. 15).

6 Cf. the special issue Doing Memory, Doing Identity: Politics of the Everyday in Contemporary Global Communities (KONTOPODIS; MATERA, 2010).

7 There is significant research about how the obesity discourse goes together with ethnic discrimination. The above-presented findings correspond with similar findings from studies of school-age children in the UK and elsewhere (AZZARITO, 2008; RAWLINS, 2009; SAGUY and ALMELING, 2008; TOMRLEY and KALOSKI NAYLOR, 2009).

8 In German the term teacher is different for early childhood education (Erzieher/-in) and for primary education (Lehrer/in); another translation of Erzieher/-in could be carer, I use the term teacher though because the German kindergarten is primarily an institution for early childhood education and not just for early childhood care.

9 The sensual and aesthetic aspects of rituals, as well as their educational dimensions, have been thoroughly studied in the context of the research cluster Performative Cultures at the Free University Berlin (WULF et al., 2001; 2004).

10 The analysis presented here is contextualized within the wider medical, social, and political discrimination that obese and overweight bodies experience in contemporary Western societies (RICH; EVANS, 2005; ROTHBLUM and SOLOVAY, 2009). It is thus situated in a broader body of critical research about obesity, biopolitics, and biopedagogies, and corresponds especially with the research direction that explores how values around food, eating, and fatness are transmitted through families and schools to children and young people (EVANSET et al., 2009; EVANSET et al., 2008; GUTHMAN, 2009; RAWLINS, 2008). While the literature on the obesity discourse and education is growing, most studies focus on school-aged children and adolescents; there is a lack of critical studies on obesity and obesity prevention with regard to preschool-aged children - a gap which the research presented here aimed to fill.

11 Throughout this history until today, a tension has existed between individualized notions of health and more population-oriented ones, leading to different dominant modes of preventive medicine in the country's different historical eras, from the Weimar Republic, Third Reich, and the post-war period to later times marked by the movement of Soziale Medizin (i.e. Weimar Republic, Third Reich, and the post-war period to later times marked by the movement of Soziale Medizin (i.e. socialized medicine, cf. NIEWÖHNER et. al., 2011).

12 "Logic" refers to discourse as well as to ways to do things in practice (see Mol 2008b).

13 The so-called National Program of School Alimentation (Programa Nacional de Alimentação Escolar) has its origin in various initiatives that took place in the 1940s-50s. It was, however, after strong social movements and only in 1988 that the provision of food in all institutions of early, primary, and secondary education became a constitutional right. This program consists in the transfer of financial resources from the Federal Government to the states, prefectures, and municipal authorities, so that they can acquire the necessary products and finance the applicable services for the distribution of school meals (merenda escolar).

14 The various aspects of everyday life within this context with a particular emphasis on schooling and pedagogics have been analyzed elsewhere (KONTOPODIS, 2012b; KONTOPODIS et al., in print), and I will not go into details here.

15 One should note here that indigenous people or other countryside communities would not collaborate with the state but would prefer to establish parallel structures such as self-organizing the provision of food for the children, selforganizing the local school, or avoiding unnecessary use of modern technology. The countryside community referred to above is thus a particular one that prioritizes a certain way of macro-politics, while the Brazilian countryside is 
too heterogeneous to consider here.

\section{References}

ALTHANS, B. ; BILSTEIN, J. (Eds.). Essen Bildung - Konsum: Pädagogisch-anthropologische Perspektiven. Wiesbaden: VS-Verlag, 2016.

AUDEHM, K. Erziehung bei Tisch: Zur Sozialen Magie eines Familienrituals. Bielefeld: transcript, 2007.

AZZARITO, L. The Rise of the Corporate Curriculum: Fatness, Fitness and Whiteness. In J. WRIGHT ; V. HARWOOD (Eds.). Biopolitics and the Obesity Epidemic: Governing Bodies London: Taylor \& Francis, 2008. p. 2-14.

DINARDO, J. Natural Experiments and Quasinatural Experiments. In: S. N. DURLAUF ; L. E. BLUME (Eds.). The New Palgrave Dictionary of Economics Online. London: Palgrave Macmillan, 2008.

http://www.dictionaryofeconomics.com/article?id=p de2008_ N000142 (date of access: 2012-09-01).

EVANS, J. ; DAVIES, B. Sociology, the Body and Health in a Risk Society. In J. EVANS, B. DAVIES ; J. WRIGHT (Eds.), Body Knowledge and Control. Studies in the Sociology of Physical Education and Health London: Routledge, 2004. p. 35-51.

EVANS, J.; DAVIES, B.; RICH, E. The Body Made Flesh: Embodied Learning and the Corporeal Device. British Journal of Sociology of Education, 30(4), 391-505, 2009.

EVANS, J.; RICH, E.; ALLWOOD, R. ; DAVIES, B. Body Pedagogies, P/policy, Health and Gender. British Educational Research Journal, 34(3), 1-16, 2008.

FICHTNER, B. "Children as Unstable Signifiers": A Dialogue Between Giorgio Agamben and Lew Sem Vygotskij. In M. KONTOPODIS (Ed.). Children, Culture and Emerging Educational Challenges: A Dialogue with Brazil, Latin America Berlin: Lehmanns Media, 2009. p. 176-192.

GUTHMAN, J. Teaching the Politics of Obesity: Insights into Neoliberal Embodiment and
Contemporary Biopolitics. Antipode: A Radical Journal of Geography, 41(5), 1110-1133, 2009.

KONTOPODIS, M. Biomedicine, Psychology and the Kindergarten: Children at Risk and Emerging Knowledge Practices. Sport, Education and Society, OnlineFirst: DOI: 10.1080/13573322.2011.605115, 2011.

KONTOPODIS, M. How Things Matter in Everyday Lives of Preschool Age Children: Material-semiotic Investigations in Psychology and Education. Journal für Psychologie, 20(2), 1-14, 2012a.

KONTOPODIS, M. Neoliberalism, Pedagogy and Human Development: Exploring Time, Mediation and Collectivity in Contemporary Schools. London and New York: Routledge/ Taylor \& Francis, 2012b.

KONTOPODIS, M.; MATERA, V. Doing Memory, Doing Identity: Politics of the Everyday in Contemporary Global Communities (Introduction to Special Issue). Outlines: Critical Practice Studies, 2, 1-14, 2010.

KONTOPODIS, M.; SCHÜTZ-FOERSTE MARGIT, G.; FOERSTE, E. (in print). „Wir Leben nicht nur vom Essen": Einschränkungen der Agrarökologie, die Gefahr des Konsumismus und die Pädagogik der Erde in der Landlosenbewegung in Brasilien. In B. ALTHANS \& J. BILSTEIN (Eds.), Ernährung - Anthropologie und Pädagogik. Wiesbaden: VS-Verlag.

Local Authorities Coordinators of Regulatory Services/ LACORS. LACORS Nursery School Nutrition Report 2010. London, UK: LACORS, $2010 . \quad$ Available at: http://www.warwickshire.gov.uk/Web/Corporate/Pa ges.nsf/Links/1BC12969F40DD162802573AF0042 C45F/\$file/LACORS+Nursery+school+nutrition+re port+2010.pdf (date of access: 30. August 2010).

MOL, A. I Eat an Apple. On Theorizing Subjectivities. Subjectivity, 22, 28-37, 2008a.

MOL, A. The logic of care: health and the problem of patient choice. Abingdon, Oxon and New York: Routledge, 2008b.

NIEWÖHNER, J. et al. C. Cardiovascular Disease and Obesity Prevention in Germany: An Investigation into a Heterogeneous Engineering 
Project. Science, Technology \& Human Values, 36(5), 723-751, 2011.

RABINOW, P. Essays on the Anthropology of Reason. Princeton, N.J.: Princeton University Press, 1996.

RAWLINS, E. Citizenship, Health Education and the UK Obesity Crisis. ACME: An International EJournal for Critical Geographies, 7(2), 135-142, 2008.

RAWLINS, E. Choosing Health? Exploring Children's Eating Practices at Home and at School. Antipode: A Radical Journal of Geography, 41(5), 1084-1109, 2009.

RICH, E.; EVANS, J. 'Fat Ethics' - The Obesity Discourse and Body Politics. Social Theory \& Health, 3, 341-358, 2005.

ROTHBLUM, E.; SOLOVAY, S. The Fat Studies Reader. New York: New York University Press, 2009.

SAGUY, A. C.; ALMELING, R. Fat in the Fire? Science, the News Media, and the "Obesity Epidemic'. Sociological Forum, 23(1), 53-83, 2008.
SHILLING, C. Foreword: Body Pedagogics, Society and Schooling. In J. EVANS; E. RICH, B. DAVIES; R. ALLWOOD (Eds.), Education, Disordered Eating and Obesity Discourse: Fat Fabrications (pp. ix-xv). London and New York: Routledge, 2008.

SPIEKERMANN, U. Vollkornbrot in Deutschland. Regionalisierende und nationalisierende Deutungen und Praktiken während der NS-Zeit. Comparativ, 11(1), 27-50, 2001.

TOMRLEY, C.; KALOSKI NAYLOR, A. Fat Studies In The UK. York: Raw Nerve Books, 2009.

WULF, C. et al. Das Soziale als Ritual: Zur performativen Bildung von Gemeinschaften. Opladen: Leske + Budrich, 2001.

WULF, C. et al. Bildung im Ritual: Schule, Familie, Jugend, Medien. Wiesbaden: Verlag für Sozialwissenschaften, 2004.

WULF, C.; ZIRFAS, J. (Eds.). Pädagogik des Performativen. Theorien, Methoden, Perspektiven. Weinheim and Basel: Beltz, 2007.

\section{About the author}

Dr Michalis Kontopodis (Dipl Psy, University of Crete \& PhD, Free University Berlin) is a Senior Lecturer and Director of the MSc Psychology and Education, associated with the Centre for Critical Psychology \& Education at the University of Sheffield.

Email: m.kontopodis@sheffield.ac.uk

Web: http://mkontopodis.wordpress.com

Twitter: @m_kontopodis.

Recebido em fevereiro de 2016.

Aprovado em agosto de 2016. 